\title{
Effect of Nutrient Management on Physiological Growth of Rice (Oryza sativa L.)
}

\author{
Vishnu $^{1}$, Vishal Verma ${ }^{2 *}$, Anil Kumar ${ }^{3}$, Shri Rakesh $^{4}$ and Gabu Singh Gathiye ${ }^{5}$ \\ ${ }^{1}$ Department of Agronomy, College of Agriculture, Jawaharlal Nehru Krishi Vishwa \\ Vidyalaya, Jabalpur Madhya Pradesh-482004, India \\ ${ }^{2}$ Division of Genetics \& Plant Propagation, Tropical Forest Research Institute, Jabalpur, \\ Madhya Pradesh-482021, India \\ ${ }^{3}$ Department of Genetics \& Plant Breeding, ${ }^{4}$ Department of Agronomy, College of \\ Agriculture, Swami Keshwanand Rajasthan Agricultural University, Bikaner, Rajasthan- \\ 334006, India \\ ${ }^{5}$ RVSKVV- Krishi Vigyan Kendra, Dhar, Madhya Pradesh- 454001, India \\ *Corresponding author
}

\section{A B S T R A C T}

\begin{tabular}{|l|}
\hline Ke y w o r d s \\
Rice, CGR, RGR, \\
NAR and LAI \\
\hline Article Info \\
\hline $\begin{array}{l}\text { Accepted: } \\
11 \text { June } 2020 \\
\text { Available Online: } \\
\text { 10 July } 2020\end{array}$ \\
\hline
\end{tabular}

\section{Introduction}

Rice (Oryza sativa L.) is the staple food crop of the world. It is major source of calories for $40 \%$ of the world population. India is the second most populous nation and the largest producer of rice in the world after China. In India, rice is covered 43.79 million ha acreage and contributing 116.42 million tonnes grain production with productivity of $2659 \mathrm{~kg} / \mathrm{ha}$ (GOI, 2019) .Cultivation of high yielding dwarf varieties high responsive to fertilizer and excess use of inorganic fertilizers has depleted the inherent soil fertility. Enhancing the rice productivity through the appropriate nutrient management has been the main thrust of Indian rice policy.

The decline or stagnation in yield has been attributed to nutrient mining and reduced use of organics (John et al. 2001). Inorganic fertilizer is one of the key factors to increase 
the rice productivity. Rice yield and biomass increased rapidly due to increased use of chemical fertilizers. Several long-term experiments conducted all over India showed that a decrease in rice productivity due to continuous use of imbalanced chemical fertilizers. As a result, agricultural ecosystems remain in a state of chemical nutrient saturation, leading to huge nutrient losses through leaching, runoff, volatilization, emissions, immobilization and subsequent low nutrient use efficiency (Zang et al., 2012).

Integrated nutrient management (INM) aims to improve soil health and sustain high level of productivity and production (Prasad et al., 1995). Singh and Kumar (2014) reported increased yield and nutrient use efficiency in rice with organics. Organic supply of nutrients at the peak period of nutrient absorption also provide micro nutrients and modify soil-physical behavior as well as increase the efficiency of applied nutrients (Pandey et al., 2007). The integrated use of use of organic and inorganic fertilizers has been reported not only to meet the nutrients need of the crop but also has been fund to sustain large scale productivity goals (Yadav and Meena 2014).

In view of above fact study on nutrient management was carried out for identifying most effective nutrient source and their optimum dose for harvesting higher physiological growth of rice.

\section{Materials and Methods}

The field experiment was conducted at AICRP IFS Research Farm, Krishi Nagar, Jawaharlal Nehru Krishi Vishwa Vidyalaya, and Jabalpur (MP), India during kharif season of 2016. The soil of experimental field was sandy clay loam, neutral in reaction $(\mathrm{pH}$ 7.2) having $269.83 \mathrm{~kg} / \mathrm{ha}$ available $\mathrm{N}$ (Alkaline permanganate method (Subbiah and Asija, 1956), medium in available phosphorus (12.7 $\mathrm{kg} / \mathrm{ha}$, Olsen's method (Olsen et al., 1954 and medium in available potassium $(283.3 \mathrm{~kg} / \mathrm{ha}$, Flame photometric method (Metson, 1956) in $0-15 \mathrm{~cm}$ soil depth at the start of the experiment.

The experiment was laid out in randomized block design with three replications. There were seven nutrient management treatments viz. $100 \% \mathrm{~N}$ through Vermicompost, $75 \% \mathrm{~N}$ through Vermicompost, 100\% NPK through fertilizers, Farmers practice N:60, P:30 through fertilizers +3 tonne FYM/ha, $50 \% \mathrm{~N}$ through Vermicompost $+50 \%$ NPK through fertilizers, $75 \% \mathrm{~N}$ through Vermicompost + $25 \%$ NPK through fertilizers and absolute control.

The Recommended dose of fertilizer was 120 $\mathrm{kg} \mathrm{N}, 60 \mathrm{P}_{2} \mathrm{O}_{5}$ and $40 \mathrm{~kg} \mathrm{~K}_{2} \mathrm{O}$ per hectare. Rice "Pusa Sugandha 1" Seedling was transplanted in first week of July with 2 to 3 seedlings/hill of 21 day of age at spacing of $20 \mathrm{~cm} \times 20 \mathrm{~cm}$. Rice was irrigated frequently to maintain $2-3 \mathrm{~cm}$ standing water in all the plots. The irrigation was stopped 10 days before harvesting of crop.

All the recommended package of practices was followed to raise the crop. The crop was harvested during first week of November, 2016. Leaf area index, crop growth rate, relative growth rate and net assimilation rate calculated by following the formula:

\section{Leaf Area Index}

Leaf area index is the ratio of leaf area to the area of ground cover. Leaf area index is calculated by dividing the leaf area plant $^{-1}$ by land area occupied by the plant. The leaf area index plant $^{-1}$ was calculated at 30, 60 and 90 DAT. After computing the leaf area $\left(\mathrm{cm}^{2}\right)$, leaf area index was calculated by using the 
following formula as suggested by Watson (1952).

$\begin{aligned} & \text { Leaf area } \\ & \text { index }(\mathrm{LAI})\end{aligned} \quad=\frac{\text { Leaf area }\left(\mathrm{cm}^{2}\right)}{\begin{array}{c}\text { Unit land area } \\ \left(\mathrm{cm}^{2}\right)\end{array}}$

\section{Crop growth rate}

The crop growth rate is defined as the increase in rate of dry weight per unit land area per unit time. It is also represents dry weight gained by a unit area of crop in a unit time. It is expressed in $\mathrm{g} \mathrm{m}^{-2} \mathrm{day}^{-1}$. The average crop growth rate was calculated as suggested by Enyi (1962). It is given as:

CGR $=\frac{W_{2}-W_{1}}{P\left(t_{2}-t_{1}\right)}$

Where, $\mathrm{W}_{2}$ and $\mathrm{W}_{1}$ are the dry matter weight of the plant at time $t_{2}$ and $t_{1}$, respectively and $\mathrm{P}$ is the ground area occupied by the plant in $\mathrm{m}^{2}$.

\section{Relative growth rate}

It is an index of the amount of growing material per unit dry weight of plant per unit time. The relative growth rate represents the dry weight gained in time interval in relation to initial weight. The mean RGR is calculated from dry weight measurement at time $t_{1}$ and $t_{2}$ suggested by Blackman (1919).

$$
\text { RGR }=\quad \frac{\log _{\mathrm{e}} \mathrm{W}_{2}-\log _{\mathrm{e}} \mathrm{W}_{1}}{\mathrm{t}_{2}-\mathrm{t}_{1}}
$$

Where, $\mathrm{W}_{2}$ and $\mathrm{W}_{1}$ are the dry matter production of the plant at time $t_{2}$ and $t_{1}$ respectively, and it is expressed in $\mathrm{mg} \mathrm{g}^{-1}$ day

\section{Net assimilation ratio}

The term NAR was used by Williams (1946). NAR is defined as dry matter increment per unit leaf area or per unit leaf dry weight per unit of time. The NAR is a measure of average photosynthetic efficiency of leaves in a crop community.

$$
\text { Net assimilation rate }(\mathrm{NAR})=\frac{\left(\mathrm{W}_{2}-\mathrm{W}_{1}\right)}{\left(\mathrm{t}_{2}-\mathrm{t}_{1}\right)} \times \frac{\left(\log _{\mathrm{e}} \mathrm{L}_{2}-\log _{\mathrm{e}} \mathrm{L}_{1}\right)}{\left(\mathrm{L}_{2}-\mathrm{L}_{1}\right)}
$$

Where,

$\mathrm{W}_{1}$ and $\mathrm{W}_{2}$ is dry weight of whole plant at time $t_{1}$ and $t_{2}$, respectively

$\mathrm{L}_{1}$ and $\mathrm{L}_{2}$ are leaf weights or leaf area at time $t_{1}$ and $t_{2}$, respectively

$t_{1}$ and $t_{2}$ are time interval in days

\section{Results and Discussion}

\section{Growth parameters}

The results (Table 1) revealed that growth parameters viz., plant height, number of tillers and dry matter accumulation of rice influenced significantly by the different fertility level. Application of $100 \%$ NPK through fertilizers recorded significantly highest plant height $(19.09,39.05,75.53 \&$ $74.52 \mathrm{~cm})$, number of tillers/hill $(8.73,14.40$, $18 \& 17.78 \mathrm{~cm})$ and dry matter accumulation $(2.95,9.73,14.35 \& 15.40 \mathrm{~g} / \mathrm{plant})$ of rice at $30,60,90 \mathrm{DAT}$ and harvest as compared to rest of treatments.

The results showed that application organic manure was not helpful in increasing plant height, tiller production and dry matter accumulation of hybrid rice; rather it reduced the plant height, tiller production and dry matter accumulation. 
Table.1 Effect of nutrient management on plant height, number of tillers and leaf area index of rice

\begin{tabular}{|c|c|c|c|c|c|c|c|c|c|c|c|c|}
\hline \multirow[t]{2}{*}{ Treatments } & \multicolumn{4}{|c|}{ Plant height (cm) } & \multicolumn{4}{|c|}{ Number of tillers/hill } & \multicolumn{4}{|c|}{ Dry matter production (g/plant) } \\
\hline & $\begin{array}{c}30 \\
\text { DAT }\end{array}$ & $\begin{array}{c}60 \\
\text { DAT }\end{array}$ & $\begin{array}{c}90 \\
\text { DAT }\end{array}$ & $\begin{array}{c}\text { Harves } \\
\mathbf{t}\end{array}$ & $\begin{array}{c}30 \\
\text { DAT }\end{array}$ & $\begin{array}{c}60 \\
\text { DAT }\end{array}$ & $\begin{array}{c}90 \\
\text { DAT }\end{array}$ & $\begin{array}{c}\text { Harves } \\
\mathbf{t}\end{array}$ & 30 DAT & $\begin{array}{c}60 \\
\text { DAT }\end{array}$ & $\begin{array}{l}90 \\
\text { DAT }\end{array}$ & Harvest \\
\hline $100 \% \mathrm{~N}$ through Vermicompost & 15.45 & 35.30 & 71.47 & 69.88 & 6.30 & 11.73 & 15.89 & 15.56 & 2.40 & 8.48 & 13.45 & 14.70 \\
\hline $75 \% \mathrm{~N}$ through Vermicompost & 14.59 & 33.45 & 70.64 & 69.03 & 5.83 & 11.20 & 15.22 & 15.11 & 1.90 & 8.33 & 13.29 & 14.35 \\
\hline $100 \%$ NPK through fertilizers & 19.09 & 39.05 & 75.53 & 74.42 & 8.73 & 14.40 & 18.00 & 17.78 & 2.95 & 9.73 & 14.35 & 15.40 \\
\hline $\begin{array}{l}\text { Farmers practice } N: 60, P: 30 \text { through } \\
\text { fertilizers }+3 \text { tonne } F Y M / h a\end{array}$ & 13.67 & 32.03 & 68.76 & 67.43 & 5.40 & 9.97 & 14.66 & 14.55 & 1.58 & 7.34 & 12.34 & 13.24 \\
\hline $\begin{array}{l}50 \% \mathrm{~N} \text { through Vermicompost }+\mathbf{5 0 \%} \\
\text { NPK through fertilizers }\end{array}$ & 16.92 & 37.37 & 74.40 & 72.49 & 7.73 & 13.17 & 17.11 & 16.78 & 2.76 & 9.19 & 14.07 & 15.34 \\
\hline $\begin{array}{l}75 \% \mathrm{~N} \text { through Vermicompost }+25 \% \\
\text { NPK through fertilizers }\end{array}$ & 16.25 & 35.89 & 73.01 & 71.04 & 7.07 & 12.50 & 16.34 & 16.22 & 2.35 & 9.02 & 13.60 & 14.50 \\
\hline Absolute control & 10.94 & 25.62 & 63.27 & 61.81 & 3.50 & 7.63 & 10.55 & 10.33 & 1.08 & 6.65 & 11.36 & 12.88 \\
\hline SEm \pm & 0.36 & 0.60 & 0.62 & 0.69 & 0.152 & 0.254 & 0.530 & 0.498 & 0.10 & 0.40 & 0.50 & 0.70 \\
\hline CD at $5 \%$ & 1.12 & 1.84 & 1.91 & 2.15 & 0.469 & 0.782 & 1.635 & 1.535 & 0.33 & 1.25 & 1.54 & 2.18 \\
\hline
\end{tabular}


Table.2 Effect of nutrient management on dry matter production, crop growth rate, relative growth rate and net assimilation rate of rice

\begin{tabular}{|c|c|c|c|c|c|c|c|c|c|c|c|c|}
\hline \multirow[t]{2}{*}{ Treatments } & \multicolumn{3}{|c|}{ Leaf area index } & \multicolumn{3}{|c|}{$\begin{array}{l}\text { Crop growth rate } \\
(\text { g/m²/day })\end{array}$} & \multicolumn{3}{|c|}{$\begin{array}{l}\text { Relative growth rate } \\
\text { (g/g/day) }\end{array}$} & \multicolumn{3}{|c|}{$\begin{array}{l}\text { Net assimilation rate } \\
\left(\mathrm{g} / \mathrm{day} / \mathrm{m}^{2}\right)\end{array}$} \\
\hline & $\begin{array}{c}30 \\
\text { DAT }\end{array}$ & $\begin{array}{l}\text { 60 } \\
\text { DAT }\end{array}$ & $\begin{array}{c}90 \\
\text { DAT }\end{array}$ & $\begin{array}{l}\text { 0-30 } \\
\text { DAT }\end{array}$ & $\begin{array}{c}30-60 \\
\text { DAT }\end{array}$ & $\begin{array}{c}60-90 \\
\text { DAT }\end{array}$ & $\begin{array}{c}30-60 \\
\text { DAT }\end{array}$ & $\begin{array}{c}60-90 \\
\text { DAT }\end{array}$ & $\begin{array}{l}90 \text { DAT } \\
\text { - } \\
\text { harvest }\end{array}$ & $\begin{array}{l}\text { 0-30 } \\
\text { DAT }\end{array}$ & $\begin{array}{c}30- \\
60 \\
\text { DAT }\end{array}$ & $\begin{array}{l}60-90 \\
\text { DAT }\end{array}$ \\
\hline $100 \% \mathrm{~N}$ through Vermicompost & 0.94 & 3.21 & 4.62 & 1.274 & 4.139 & 5.253 & 0.482 & 0.308 & 0.167 & 0.075 & 0.057 & 0.017 \\
\hline $75 \% \mathrm{~N}$ through Vermicompost & 0.85 & 3.03 & 4.24 & 1.060 & 4.113 & 5.111 & 0.465 & 0.233 & 0.156 & 0.060 & 0.055 & 0.016 \\
\hline $100 \%$ NPK through fertilizers & 1.18 & 4.00 & 5.91 & 1.703 & 5.033 & 5.650 & 0.656 & 0.390 & 0.193 & 0.099 & 0.063 & 0.020 \\
\hline $\begin{array}{l}\text { Farmers practice N:60, P:30 through } \\
\text { fertilizers }+3 \text { tonne FYM/ha }\end{array}$ & 0.71 & 2.78 & 3.89 & 0.918 & 3.513 & 4.800 & 0.435 & 0.166 & 0.137 & 0.053 & 0.052 & 0.015 \\
\hline $\begin{array}{l}50 \% \mathrm{~N} \text { through Vermicompost }+\mathbf{5 0 \%} \mathrm{NPK} \\
\text { through fertilizers }\end{array}$ & 1.09 & 3.55 & 5.56 & 1.561 & 4.174 & 5.516 & 0.555 & 0.367 & 0.188 & 0.092 & 0.059 & 0.019 \\
\hline $\begin{array}{l}75 \% \mathrm{~N} \text { through Vermicompost }+25 \% \mathrm{NPK} \\
\text { through fertilizers }\end{array}$ & 1.07 & 3.39 & 5.40 & 1.362 & 4.155 & 5.489 & 0.534 & 0.314 & 0.170 & 0.079 & 0.058 & 0.018 \\
\hline Absolute control & 0.33 & 1.37 & 1.96 & 0.606 & 1.941 & 2.970 & 0.416 & 0.120 & 0.127 & 0.042 & 0.041 & 0.014 \\
\hline SEm \pm & 0.01 & 0.05 & 0.05 & 0.196 & 0.526 & 0.319 & 0.027 & 0.014 & 0.004 & 0.004 & 0.003 & 0.001 \\
\hline CD at $5 \%$ & 0.03 & 0.17 & 0.17 & 0.610 & 1.638 & 0.994 & 0.084 & 0.044 & 0.014 & 0.012 & 0.010 & 0.003 \\
\hline
\end{tabular}


This might be due to its inability to supply nutrients as per demand of hybrid rice because of its slow release particularly at the early vegetative stages.

\section{Growth indices}

The results (Table 2) revealed that leaf area index, crop growth rate, relative growth rate and net assimilation rate influenced by nutrient management. The LAI increased steadily up to 90 DAT. Significantly greater values of LAI were recorded in crop with $100 \%$ NPK through fertilizers $(1.18,4.0$, and 5.91) at 30, 60 DAT and 90 DAT as compared to rest of treatments. The results showed that application organic manure was not helpful in increasing LAI of hybrid rice; rather it reduced the LAI values. This might be due to its inability to supply nutrients as per demand of hybrid rice because of its slow release particularly at the early vegetative stages.

The duration of LAI maintaining above 5.0 is more important than the maximum LAI on influencing the crop productivity (Wang et al., 2001). Application of $100 \%$ NPK through fertilizers recorded significantly highest crop growth rate $\left(1.73,5.033,5.650 \mathrm{~g} / \mathrm{m}^{2} /\right.$ day $)$ between $0-30,30-60,60-90$ DAT, relative growth rate $(0.656,0.390,0.193 \mathrm{~g} / \mathrm{g} /$ day $)$ between $30-60,60-90$ DAT, 90 DAT harvest and net assimilation rate $(0.099$, 0.063, $0.020 \mathrm{~g} / \mathrm{day} / \mathrm{m}^{2}$ ) between $0-30,30-60$, $60-90$ DAT. Application of $100 \%$ NPK through fertilizers had a tendency of producing higher crop CGR, RGR and NAR values than other treatments during most of the periods.

In conclusion on the basis of present experiment, it may be concluded that application of $100 \%$ NPK through fertilizers overall better than other treatments. It gives higher values of growth parameters

\section{References}

Blackman, V.H. (1919) The compound interest law and plant growth. Annals of Botany 33: 353-360.

Enyi, B. A. I. (1962) Annals of Botany 26: 467-487.

GOI (2019) Pocket Book of Agricultural Statistics 2019, Ministry of agriculture \& Farmers Welfare Department of agriculture, cooperation \& Farmers Welfare Directorate of Economics \& Statistics New Delh.

Iqbal, M. T. 2004. "Yield and Biomass in Rice Interactions of Nitrogen, Phosphorous and Water Application." Pakistan Journal of Biological Sciences 7 (12): 2115-20.

John, P.S., George, M. and Jacob, R.Z. (2001) Nutrient mining in agro-climatic zones of Kerala, Fertilizer News 46:45-52 and 5557.

Metson, A. I. (1956) Method of chemical analysis for survey samples. Bulletin No. 2 Department Science. Mediterranean Research soil Bureau 12.

Olsen, S.R., Cole, C.V., Watnabe, F.S. and Dean, L A. (1954) Estimation of available phosphorus in soils by extraction with sodium bicarbonate. USDA. Circular, 939: 18.

Prasad, B., Prasad J., and Prasad (1995) Nutrient management for sustained rice and wheat production in calcareous soil amended with green manures, organic manure and zinc. Fertilizers News 40 (3):39-41.

Singh, D. and Kumar, A. (2014) Effect of sources of nitrogen on growth, yield and uptake of nutrient in rice. Annals of Plant and Soil Research 16(4): 359-361.

Subbiah, B.V. and Asija, G.L. (1956) A rapid procedure for the estimation of available nitrogen in soils. Current Science 25: 259260.

Wang, G. H., Dobermann, A., Witt, C., Sun, Q. Z., and Fu, R. X. 2001. "Performance of 
Site-Specific Nutrient Management for Irrigated Rice in Southeast China." Agronomy Journal 93 (4): 869-78.

Watson, D.J. 1952. The physiological basis of variation in yield. Advances in Agronomy. 6: 103-109.

Williams, R.F (1946). The physiology of plant growth with special reference to the concept of net assimilation rate. Annals of Botany, Volume 10, Issue 1, Pages 41-72.

Yadav, L., and Meena .N. (2014)
Performance of aromatic rice (Oriza sitiva) genotype as influenced by integrated nitrogen management. Indian Journal of Agronomy 59(2): 51-255.

Zhang, F. S., Cui, Z. L., Chen, X. P., Ju, X. T., Shen, J. B., Chen, Q., Liu, X. J., Zhang, W. F., Mi, G. H., Fan, M. S., and Jiang, R. F. 2012. "Integrated Nutrient Management for Food Security and Environmental Quality in China." Advances in Agronomy 116: 1-40.

\section{How to cite this article:}

Vishnu, Vishal Verma, Anil Kumar, Shri Rakesh and Gabu Singh Gathiye. 2020. Effect of Nutrient Management on Physiological Growth of Rice (Oryza sativa L.). Int.J.Curr.Microbiol.App.Sci. 9(07): 1223-1229. doi: https://doi.org/10.20546/ijcmas.2020.907.141 